\title{
Avian Botulism Type C in a Commercial Poultry Farm: First Report in Central America
}

\author{
Evelyn Rodríguez-Cavallini ${ }^{1}$, Diana López-Ureña ${ }^{1}$, Tania Román ${ }^{2}$ and Carlos Quesada-Gómez ${ }^{1,3^{*}}$ \\ ${ }^{1}$ Facultad de Microbiología and Centro de Investigación en Enfermedades Tropicales, Universidad de Costa Rica. San José, Costa Rica \\ ${ }^{2}$ Corporación Pipasa, 40702, Heredia, Costa Rica \\ ${ }^{3}$ Laboratorio de Ensayos Biológicos (LEBi), Universidad de Costa Rica. San José, Costa Rica
}

*Corresponding author: Dr. C Quesada-Gómez, Facultad de Microbiología and Centro de Investigación en Enfermedades Tropicales, Universidad de Costa Rica. 2060, Montes de Oca, San José, Costa Rica, E-mail: carlos.quesada@ucr.ac.cr

Received date: March 09, 2018; Accepted date: March 19, 2018; Published date: March 26, 2018

Copyright: @2018 Rodríguez-Cavallini, et al. This is an open-access article distributed under the terms of the Creative Commons Attribution License, which permits unrestricted use, distribution, and reproduction in any medium, provided the original author and source are credited.

\begin{abstract}
Avian botulism outbreaks are frequently produced by type $\mathrm{C}$ neurotoxin secreted by Clostridium botulinum proliferating in decomposing bird carcasses and contaminated soils or water sediments. In this study, a botulism outbreak was diagnosed in broilers from a Costa Rican commercial farm through clinical signs, absence of postmortem histopathological lesions, and the confirmation of toxin in the serum of the birds. C. botulinum was furthered isolated from the intestine of these animals. This is the first report of avian botulism due to $C$. botulinum type $\mathrm{C}$ in Central America.
\end{abstract}

Keywords: Avian botulism; Central america; Poultry

\section{Case Report}

Botulinum neurotoxins (BoNTs) are potent neurotoxins which cause botulism disease. These are produced by various species of clostridia and eight types of BoNTs have been identified (designated with a letter A-H) [1] C. botulinum produces BoNT types A-F and $\mathrm{H}$. $C$. baratii produces type $\mathrm{F}, C$. butyricum BoNT type $\mathrm{E}$ and $C$. argentinense BoNT type $\mathrm{G}[1,2]$. BoNT types $\mathrm{A}, \mathrm{B}, \mathrm{E}, \mathrm{F}$ and $\mathrm{H}$ cause disease in humans, types $\mathrm{B}$ and $\mathrm{D}$ cause botulism in herbivorous mammals (equine and cattle) and type $\mathrm{C}$ mainly affects birds [3]. Also, recombinant toxins $(\mathrm{C} / \mathrm{D})$ have been described in some cases of avian botulism [2].

C. botulinum spores can survive in soils and water sediments and produce toxins in anaerobic microenvironments including stagnant waters, carcasses of dead animals, and decaying organic matter [4]. Floods, pesticides and other agricultural pollutants can lead to changes in the ecosystem that promote BoNT production [5]. Insect larvae and other flying invertebrates may concentrate BoNTs in their body $[2,4,5]$, then vertebrate animals may ingest these invertebrates along with the toxin. In vertebrates, BoNT alters the neuromuscular junction and prevents the release of acetylcholine in nerve synapses, hindering muscle contraction $[2,6]$. Finally, progressive flaccid paralysis occurs in intoxicated animals resulting in respiratory failure and death [6].

One human case of botulism has been reported in Costa Rica [7]. Also, C. botulinum has been isolated from soils in this country [8]. However, there are no reports of botulism in other Central American countries. Thus, the aim of the present study is to report the first botulism outbreak in poultry in Central America.

An initial group of broiler chickens (15 weeks old) showed tremors, flaccid paralysis in the wings, closed eyes, and twisted neck. Four weeks after the onset of symptoms, 2000 animals died. Dead animals showed no macroscopic or histopathological alterations in their liver, lungs, kidney, gizzard, spleen, intestine and heart. Parasites (protozoa and helminthes), and bacterial pathogens (mainly Salmonella and Escherichia coli) were not detected in the organs and blood cultures.

Intestinal and serum samples from sick animals as well as wood shavings, water and food samples given to the chickens, were sent to the Laboratorio de Investigación en Bacteriología Anaerobia (LIBA), University of Costa Rica under suspicion of botulism.

In order to demonstrate the presence of BoNT, lethality and neutralization assays were performed in Swiss mice (20-25 g) (approved by the Animal Care and Use Committee of the Universidad de Costa Rica, protocol CICUA 07-13). Serum samples were inoculated intraperitoneally and $C$. botulinum monovalent anti-toxin types $\mathrm{A}, \mathrm{B}, \mathrm{C}, \mathrm{D}$ and polyvalent (ABCDEF) anti-toxins (provided by the Center for Disease Control and Prevention (CDC, Atlanta, USA) were used for neutralization tests. Serum samples heated for $10 \mathrm{~min}$ at $80^{\circ} \mathrm{C}$ were used in the control group [6].

For bacterial isolation $25 \mathrm{ml}$ of water and $25 \mathrm{~g}$ of intestine, wood shavings and food samples were homogenized in $50 \mathrm{ml}$ of $0.85 \%$ saline solution. Each suspension was inoculated in two tubes of pre-reduced Chopped Meat (CM) (Oxoid, Cheshire, England). One of the inoculated broths for each sample was heated at $80^{\circ} \mathrm{C}$ for $10 \mathrm{~min}$ in order to eliminate other bacteria and induce sporulation, and then these were incubated at $30^{\circ} \mathrm{C}$ for 5 days. The rest of the samples were incubated under the same conditions $[9,10]$. Then, all tubes were centrifuged at $12,000 \mathrm{rpm}$ for $10 \mathrm{~min}$ at $4^{\circ} \mathrm{C}$ and supernatants were used for lethality assays in mice, as indicated above. Pellets of each tube were inoculated onto Egg Yolk Agar (Oxoid, Cheshire, England) plates, which were then incubated at $30^{\circ} \mathrm{C}$ for $48 \mathrm{~h}$, under anaerobic conditions. Lipase positive isolates were furthered identified using ID 32A system (BioMeriuex, Marcy l'Etoile, France) [2]. C. botulinum isolates were inoculated in $\mathrm{CM}$ broth and incubated at $30^{\circ} \mathrm{C}$ for $72 \mathrm{hr}$. Supernatants from these cultures were used for toxigenic and neutralization assays in male Swiss mice (20-25 g), as noted above. 
Citation: Rodríguez-Cavallini E, López-Ureña D, Román T, Quesada-Gómez C (2018) Avian Botulism Type C in a Commercial Poultry Farm: First Report in Central America. J Bacteriol Parasitol 9: 337. doi:10.4172/2155-9597.1000337

Page 2 of 2

Toxicity assays in mice indicated that a heat-labile toxin was present in the serum of sick poultry, as animals treated with serum samples died, while animals treated with heated serum survived. The activity of BoNT in the sera was neutralized with polyvalent antiserum and with a specific serum anti-toxin C. Inoculated animals treated with anti- A, $\mathrm{B}$, or $\mathrm{D}$ did not survive.

The supernatants of the cultures from food and water samples were non-toxigenic in the animal model assay. On the other hand, supernatants of intestinal and wood shavings samples that had been previously heated for $10 \mathrm{~min}$ at $80^{\circ} \mathrm{C}$ and incubated for 5 days were toxigenic. The effect induced by the supernatants was neutralized with anti-toxin C. C. botulinum was then isolated from wood shavings from the poultry houses and its toxigenic potential was demonstrated in the animal model. This effect was neutralized with anti-toxin C.

\section{Discussion}

The $C$. botulinum type $\mathrm{C}$ outbreak reported occurred on a poultry commercial farm. Possible causes for this outbreak could be that the animals may have fed from fly larvae and dead birds, which contain a high concentration of toxins $[2,4]$. Furthermore, in the surroundings of the henhouses a small swamp was located. This body of water eventually became dry and may have encouraged an increase in temperature providing the necessary conditions for the rapid replication of $C$. botulinum [9]. In fact, the presence of $C$. botulinum was demonstrated in the sediment around poultry houses (data not shown).

The occurrence of type $\mathrm{C}$ botulism is quite rare in carnivores. There are few reports in dogs, lions and cats [3] and although there is risk for human disease, no cases have been reported in humans [10]. To our knowledge, this is the first report of a documented case of avian botulism in Central America. This situation should be of concern for veterinarian health and scientific authorities.

\section{References}

1. Koluman A, Golcu BM, Derín O, Özkok S, Anniballi F (2013) Clostridium botulinum in honey: prevalence and antibiotic susceptibility of isolated strains. Turkish J Vet Anim Sci 37: 706-711.

2. Woudstra C, Skarin H, Anniballi F, Fenicia L, Bano L, et al. (2012) Neurotoxin gene profiling of Clostridium botulinum types C and D native to different countries within Europe. Appl Environ Microbiol 78: 3120-3127.

3. Elad D, Yas-Natan E, Aroch I, Shamir MH, Kleinbart S, et al. (2004) Natural Clostridium botulinum type C toxicosis in a group of cats. J Clin Microbiol 42: 5406-5408.

4. Alves GG, Silva ROS, Pires PS, Salvarani FM, de Oliveira Junior CA, et al. (2013) Surto de botulismo tipo C em frangos na cidade de Pancas, Espírito Santo, Brasil. Semin Ciências Agrárias 34: 355-358.

5. Takeda M, Tsukamoto K, Kohda T, Matsui M, Mukamoto M, et al. (2005) Characterization of the Neurotoxin Produced by Isolates Associated with Avian Botulism. Avian Dis 49: 376-381.

6. Caya JG, Agni R, Miller JE (2004) Clostridium botulinum and the clinical laboratorian: a detailed review of botulism, including biological warfare ramifications of botulinum toxin. Arch Pathol Lab Med 128: 653-662.

7. Hernández-de Mezerville M, Rojas-Solano M, Gutierrez-Mata A, Hernández-Con L, Ulloa-Gutierrez R (2014) Infant botulism in Costa Rica: first report from Central America. J Infect Dev Ctries 8: 123-125.

8. del Mar Gamboa M, Rodríguez E, Vargas P (2005) Diversity of mesophilic clostridia in Costa Rican soils. Anaerobe 11: 322-326.

9. Lindström $M$, Keto $R$, Markkula $A$, Nevas $M$, Hielm $S$, et al. (2001)Multiplex PCR assay for detection and identification of Clostridium botulinum types A, B, E, and F in food and fecal material. Appl Environ Microbiol 67: 5694-5699.

10. Hardy SP, Kaldhusdal M (2013) Type C and C/D toxigenic Clostridium botulinum is not normally present in the intestine of healthy broilers. Vet Microbiol 165: 466-468. 